\title{
31. Virtual water: Some reservations
}

\author{
Ramaswamy R. lyer \\ Steering Committee on Water, India
}

J.A. (Tony) Allan's concept of virtual water, now two decades old (see Allan 2003), is widely regarded as a major contribution to the discourse on water, and it received the accolade of the Stockholm Water Prize in 2008. The concept has been theoretically challenged (Merrett 2003; Iyer 2008). Allan's statement that the concept is a descendant of the Ricardian theory of 'comparative advantage' (Allan 2003) has been questioned, and it has been argued that the two concepts might lead to different practical results in a given situation, that the concept can be misleading as a policy prescription, and that production and trade decisions by countries are based on many other considerations (Wichelns 2010). The concept has, however, gained common currency, along with its offshoot 'virtual water trade', and scholarly literature on the subject is growing (see Yang et al. 2006; Hoekstra 2003; Zimmer and Renault 2003; Siebert and Doll 2010; Dalin et al. 2012).

Merrett (2003) puts forward two criticisms of the concept. His first point is that what goes into the production of rice or wheat is real water and not virtual water. That is true enough, perhaps even obvious. At the production stage, the water is indeed real. It is when the rice or wheat is traded that the concept of virtual water comes into play: we can then say that when a country exports rice or wheat it is 'virtually' exporting the water that had gone into its production.

Merrett's second point is that the terms 'virtual water' and 'import of virtual water' are unnecessary. He refers to this as a case of the application of Occam's razor; that is, in the context of agriculture, 'virtual water' can be replaced by 'the crop water requirements of food exports' and 'the import of virtual water' can be replaced by 'the import of food'.

Let me now state my critique of the concept, which is on somewhat different lines. I agree with the proposition that the concept of virtual water is useful as a warning signal to countries (or areas within a country) to be aware of the quantity of water that goes into what they produce and consume or export. Here I differ from Merrett. I do, however, have to qualify my acceptance of the concept with two reservations.

First, in the context of the general dominance today of a certain economic philosophy, there is a tendency to misuse the ideas of 'virtual water' and 'virtual water trade' in international forums as instruments for the doctrinaire advocacy of neo-liberal economic prescriptions. What I am referring to is the 
strong advocacy of the opening up of the markets of developing coutries to imports from developed coutries. In that pressure the concept of virtual water tends to become one more argument against domestic production. We need to be wary of that tendency, though of course Allan cannot be held responsible for it.

Secondly, while it is in order to say that large quantities of water are used in the production of certain agricultural commodities or industrial products, and that the export of those commodities or products is therefore virtually like exporting water, it does not follow that water is being in reality exported. The term 'virtual export of water' has become 'export of virtual water', and this leads on to the further term 'virtual water trade'. 'Virtual water' tends to be regarded as a real commodity in which trade is taking place, and this in turn leads to the compilation of statistics of that unreal trade. This is an instance of what Wittgenstein might have called the bewitchment of the intelligence by language.

At the risk of stating the obvious, it needs to be said that when a country exports or imports sugar or rice or cotton, it is exporting or importing sugar or rice or cotton, and not water. (Merrett (2003) makes this point, but in a different way.) It is misleading to talk about 'virtual water trade' in this context. The only trade in water is where (real) water itself is traded in bottled form or in the form of soft drinks, or in exceptional cases of exports or imports of water in bulk.

Further, the water needed to produce a product is not the same thing as the water content of that product. This is another reason why the concept of 'virtual water trade' is misleading. (Allan had initially used the term 'embedded water', which he rightly corrected later to 'virtual water', but a bit of that original error seems to be surviving in the new term.)

A water-rich country may import a product instead of producing it domestically for various reasons, which have nothing to do with water. A water-short country may import a commodity or product because it does not have enough water to produce it, or for various other reasons, but it may not think of the import of that commodity or product as an import of water. The statement that a country that is not well endowed with natural resources may have to depend on imports is a statement of the obvious; there is no need for a concept of 'virtual water trade' to explain this. To regard such imports/exports of commodities or products as 'water trade' seems a seriously misleading proposition.

I am not arguing against the concept of 'virtual water' as a means of promoting an awareness of the water implications of the production or export of certain commodities or products. It is indeed useful for that purpose. The concept is also a useful adjunct to that of 'water footprint'. 'Virtual water', however, is a 
metaphor, and we must not push that metaphor too far and muddle ourselves into thinking that there is a real commodity called 'virtual water' and that there is a large international trade in it.

Incidentally, every export can be re-described with reference to what has gone into the production. If exports of rice and wheat can be treated as exports of water, they can also be treated as exports of fertilisers and pesticides; exports of iron ore, and of iron and steel produced from iron ore, can be regarded as exports of the soil of the country because the ore is part of that soil (or of coal because coal is used in the conventional blast furnace); exports of aluminium products can be described as exports of electricity because aluminium is produced in electric smelters; and so on. Should we then create concepts of 'virtual fertilisers/pesticides', 'virtual soil', 'virtual coal', 'virtual electricity', and so on, and compile statistics of those virtual trades? Water is of course a special case because of its importance in our lives and its scarcity. The point that

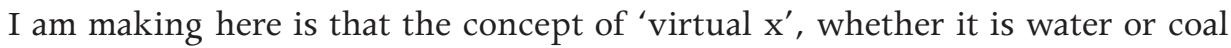
or electricity or whatever, has essentially the cautionary purpose of drawing attention to what goes into the production of a certain crop or commodity, so that a producer/exporter can make an informed decision as to the production of that crop or commodity for domestic sale or export. It is fallacious to stretch that purpose and treat these as cases of virtual trade in $\mathrm{x}$.

Besides, the theorists of virtual water trade fail to note an asymmetry between exporting and importing countries.

Trade implies two parties - a seller and a buyer. Even if we grant that the country selling rice needs to be aware that it is indirectly selling water, it does not follow that the country buying rice from abroad needs to be (or is in fact) aware that it is indirectly buying water. As already mentioned, it may have decided to import rice for various reasons unconnected with water, and may not be interested in or conscious of the water that has gone into the production process. If so, how can we talk about 'trade' in virtual water?

Reimer proposes the terminology of 'trade in water services' (Reimer 2012). It may be an improvement on 'trade in virtual water', but it is difficult to see how it is an answer to the questions raised by me. Is the importing country aware of or even interested in the fact that 'water services' have gone into the production of the commodity or product that it is importing? If not, how can we talk about trade in water services?

It will be seen that while Merrett (2003) says that (at the production stage) real water is mistakenly described as virtual water, I point out that in the context of trade, 'virtual' water is mistakenly treated as real water. Both are valid and necessary criticisms. 
Global Water: Issues and Insights

Ramaswamy R. Iyer is a former Secretary of Water Resources in the Government of India and was Research Professor at the Centre for Policy Research (CPR), New Delhi, where he worked on water-related issues and, in particular, on cooperation on river waters by India, Nepal and Bangladesh. As well as publishing numerous articles and academic books, he is chairman of a number of boards, has been a member of many government committees and commissions, and has undertaken consultancy assignments for the World Bank, International Water Management Institute, United Nations Development Programme, the European Commission and the World Commission on Dams among others. Currently, Iyer is a member of the Steering Committee on Water as well as of the Working Group on Water Governance set up by the Planning Commission as part of the preparation for the 12th Plan, and chairman of the sub-group on a draft National Water Framework Law.

\section{References}

Allan, J.A., 2003. 'Virtual water - the water, food, and trade nexus: useful concept or misleading metaphor?', Water International, 28(1):pp 4-11.

Dalin, C., Konar, M., Hanasaki, N., Rinaldo, A. and Rodriguez-Iturbe, I., 2012. 'Evolution of the global virtual water trade network', Proceedings of the National Academy of Sciences 109(16): 5989-94.

Hoekstra, A.Y. (ed.), 2003. Virtual Water Trade - Proceedings of the International Expert Meeting on Virtual Water Trade, IHE Delft, the Netherlands.

Iyer, R.R., 2008. 'Water: a critique of three concepts', Economic and Political Weekly, 43(1):15-18.

Reimer, Jeffrey J., 2012. 'Virtual water trade means trade in water services', Economics, 7 August.

Merrett, S., 2003. 'Virtual water and Occam's razor', Occasional Paper 62, School of Oriental and Asian Studies Water Issues Study Group, University of London.

Siebert, S. and Doll, P., 2010. 'Quantifying blue and green virtual water contents in global crop production as well as potential production losses without irrigation', Journal of Hydrology 384(3-4):198-217.

Wichelns, D., 2010. 'Virtual water: a helpful perspective, but not a sufficient policy criterion', Water Resources Management 24(10):2203-19. 
Yang, H., Wang, L., Abbaspour, K.C. and Zehnder, A.J.B., 2006. 'Virtual water highway: water use efficiency in global food trade', Hydrology and Earth System Sciences, Discussions 3:1-26.

Zimmer, D. and Renault, D., 2003. Virtual Water in Food Production and Global Trade - review of methodological issues and preliminary results, World Water Council, FAO-AGLW. 
This text taken from Global Water: Issues and Insights by R. Quentin Grafton, Paul Wyrwoll, Chris White and David Allendes, published May 2014 by ANU Press, The Australian National University, Canberra, Australia. 